\title{
Interactions of the apolipoprotein C-III 3238C>G polymorphism and alcohol consumption on serum triglyceride levels
}

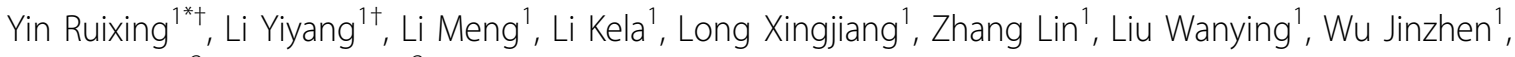
Yang Dezhai', Lin Weixiong ${ }^{2}$

\begin{abstract}
Background: Both apolipoprotein (Apo) C-III gene polymorphism and alcohol consumption have been associated with increased serum triglyceride (TG) levels, but their interactions on serum TG levels are not well known. The present study was undertaken to detect the interactions of the ApoC-III 3238C >G (rs5128) polymorphism and alcohol consumption on serum TG levels.

Methods: A total of 516 unrelated nondrinkers and 514 drinkers aged 15-89 were randomly selected from our previous stratified randomized cluster samples. Genotyping of the ApoC-III 3238C >G was performed by polymerase chain reaction and restriction fragment length polymorphism combined with gel electrophoresis, and then confirmed by direct sequencing. Interactions of the ApoC-III 3238C > G genotype and alcohol consumption was assessed by using a cross-product term between genotypes and the aforementioned factor.

Results: Serum total cholesterol (TC), TG, high-density lipoprotein cholesterol (HDL-C), ApoA-I and ApoB levels were higher in drinkers than in nondrinkers $(P<0.05-0.001)$. There was no significant difference in the genotypic and allelic frequencies between the two groups. Serum TG levels in nondrinkers were higher in CG genotype than in $C C$ genotype $(P<0.01)$. Serum TC, TG, low-density lipoprotein cholesterol $(L D L-C)$ and ApoB levels in drinkers were higher in GG genotype than in CC or CG genotype ( $P<0.01$ for all). Serum HDL-C levels in drinkers were higher in $C G$ genotype than in CC genotype $(P<0.01)$. Serum TC, TG, HDL-C and ApoA-I levels in CC genotype, TC, HDL-C, ApoA-I levels and the ratio of ApoA-I to ApoB in CG genotype, and TC, TG, LDL-C, ApoA-I and ApoB levels in $\mathrm{GG}$ genotype were higher in drinkers than in nondrinkers $(P<0.05-0.01)$. But the ratio of ApoA-I to ApoB in $G G$ genotype was lower in drinkers than in nondrinkers $(P<0.01)$. Multivariate logistic regression analysis showed that the levels of TC, TG and ApoB were correlated with genotype in nondrinkers $(P<0.05$ for all). The levels of TC, LDL-C and ApoB were associated with genotype in drinkers $(P<0.01$ for all). Serum lipid parameters were also correlated with age, sex, alcohol consumption, cigarette smoking, blood pressure, body weight, and body mass index in both groups.
\end{abstract}

Conclusions: This study suggests that the ApoC-III 3238CG heterozygotes benefited more from alcohol consumption than CC and GG homozygotes in increasing serum levels of HDL-C, ApoA-I, and the ratio of ApoA-I to $A p o B$, and lowering serum levels of TC and TG.

\footnotetext{
* Correspondence: yinruixing@yahoo.com.cn

† Contributed equally

'Department of Cardiology, Institute of Cardiovascular Diseases, the First Affiliated Hospital, 22 Shuangyong Road, Nanning 530021, Guangxi, People's Republic of China

Full list of author information is available at the end of the article
} 


\section{Introduction}

Coronary artery disease (CAD) is the most common cause of death in industrialized countries with evidence that high plasma or serum triglyceride (TG) concentration is an independent risk factor [1-5]. It is well known that plasma TG concentration is modulated by both environmental and genetic factors [6]. Numerous studies have evaluated the influence of alcohol intake, an index of lifestyle, on plasma lipid and lipoprotein concentrations. Alcohol consumption can promote lipogenesis [7] and accordingly increase serum TG levels [8,9]. Alcohol in doses $>30 \mathrm{~g} /$ day in both sexes can augment the TG level. It has been found that the alcohol intake of $60 \mathrm{~g} /$ day increases the TG level by about $0.19 \mathrm{mg} / \mathrm{dl}$ per 1 gram of alcohol consumed [10].

Plasma apolipoprotein (Apo) C-III is a major component of TG-rich lipoproteins (chylomicrons and very low density lipoprotein) and a minor component of high density lipoprotein. The mature 79-amino-acid ApoC-III protein is synthesized predominantly in the liver but also to a lesser extent in the intestine. In vitro studies have indicated that ApoC-III is a noncompetitive inhibitor of lipoprotein lipase, thereby suggesting an important role in the catabolism of TG-rich lipoproteins [11]. Plasma ApoC-III concentrations were positively correlated with plasma TG levels, both in the normal population as well as in hypertriglyceridemic patients [12] or in transgenic animals [13]. ApoC-III gene has been mapped to chromosome 11q23.3 [14] and is flanked by the genes for ApoA-I and ApoA-IV in a 15-kb gene cluster [15]. Several polymorphic sites have been detected within and around the ApoC-III gene. The most extensively studied is the SstI polymorphism, due to a $\mathrm{C} \rightarrow \mathrm{G}$ substitution at nucleotide 3238 , in the $3^{\prime}$ untranslated region of the gene. Numerous studies have found an association between the presence of a polymorphic SstI site in the untranslated region of the ApoC-III gene with raised ApoC-III and TG concentrations [16-53] and with an increased risk of CAD [53-62]. However, little is known about the interactions of the ApoC-III gene polymorphism and alcohol consumption on serum lipid concentrations. Therefore, the aim of the present study was to determine the interactions of the ApoC-III 3238C >G (rs5128) polymorphism and alcohol consumption on serum lipid levels.

\section{Materials and methods Study subjects}

A total of 1030 unrelated subjects who reside in 16 villages in Napo County, Guangxi Zhuang Autonomous Region, People's Republic of China were randomly selected from our previous stratified randomized cluster samples [63]. The age of the subjects ranged from 15 to
89 years, with an average age of $43.30 \pm 17.69$ years. There were 516 nondrinkers and 514 drinkers. All of the subjects were peasants. The study subjects were essentially healthy and had no evidence of diseases related to atherosclerosis, CAD and diabetes. None of them had been treated with $\beta$-adrenergic blocking agents and lipid-lowering drugs such as statins or fibrates. The present study was approved by the Ethics Committee of the First Affiliated Hospital, Guangxi Medical University. Informed consent was obtained from all subjects after they received a full explanation of the study.

\section{Epidemiological survey}

The survey was carried out using internationally standardized methods, following a common protocol. Information on demographics, socioeconomic status, and lifestyle was collected with standardized questionnaires. Smoking status was categorized into groups of cigarettes per day: $<20$ and $\geq 20$. Alcohol consumption was categorized into groups of grams of alcohol per day: $\leq 25$ and $>25$. The physical examination included blood pressure, body height, and body weight, and body mass index (BMI) was calculated as weight $(\mathrm{kg})$ divided by height $(\mathrm{m})$ squared. Sitting blood pressure was measured three times with use of a mercury sphygmomanometer after the subjects had a 5-minute rest, and the average of the three measurements was used in statistical analysis. Systolic blood pressure was determined by the first Korotkoff sound, and diastolic blood pressure by the fifth Korotkoff sound.

\section{Biochemical analysis}

Venous blood samples $(8 \mathrm{ml})$ were drawn from a forearm vein of every subject after venous occlusion for a few seconds in a sitting position, after an overnight fast of $12 \mathrm{~h}$ and abstention from alcohol use for at least $12 \mathrm{~h}$. A part of the sample $(3 \mathrm{ml})$ was collected into glass tubes and allowed to clot at ambient temperature, and used to determine serum lipid levels, and another part of the sample $(5 \mathrm{ml})$ was transferred into tubes with anticoagulate solution $(4.80 \mathrm{~g} / \mathrm{L}$ citric acid, $14.70 \mathrm{~g} / \mathrm{L}$ glucose, and $13.20 \mathrm{~g} / \mathrm{L}$ tri-sodium citrate) and used to extract deoxyribonucleic acid (DNA). Immediately following clotting serum was separated by centrifugation for 15 minutes at $3000 \mathrm{rpm}$. The levels of serum total cholesterol (TC), TG, high-density lipoprotein cholesterol (HDL-C), and low-density lipoprotein cholesterol (LDL-C) in samples were determined by enzymatic methods with commercially available kits, Tcho-1, TG-LH (RANDOX Laboratories Ltd., Ardmore, Diamond Road, Crumlin Co. Antrim, United Kingdom, BT29 4QY), Cholestest N HDL, and Cholestest LDL (Daiichi Pure Chemicals Co., Ltd., 
Tokyo, Japan), respectively. Serum ApoA-I and ApoB levels were assessed by the immunoturbidimetric immunoassay using a commercial kit (RANDOX Laboratories Ltd.). All determinations were performed with an autoanalyzer (Type 7170A; Hitachi Ltd., Tokyo, Japan) in the Clinical Science Experiment Center of the First Affiliated Hospital, Guangxi Medical University.

\section{DNA amplification and genotyping}

Total genomic DNA was isolated from peripheral blood leukocytes using the phenol-chloroform method. The extracted DNA was stored at $4^{\circ} \mathrm{C}$ until analysis. Genotyping of the ApoC-III 3238C >G was performed by polymerase chain reaction and restriction fragment length polymorphism (PCR-RFLP) according to the previous reports [19]. The sequence of the forward and backward primers used was 5'-CACTAGCCCAGAGAGAGGAGTGCC-3' and 5'-CTGAGCCCAGCCGCACACTAA-3' (Sangon, Shanghai, China). Each reaction system of a total volume of $25 \mu \mathrm{L}$, comprised $0.2 \mu \mathrm{g}$ of genomic DNA; $1.0 \mu \mathrm{L}$ of each primer $(10 \mathrm{pmol} / \mu \mathrm{l})$; $2.5 \mu \mathrm{L}$ of $10 \times$ buffer solution; $1.5 \mu \mathrm{L}$ of $\mathrm{MgCl}_{2}$ $(25 \mathrm{mmol} / \mathrm{L}) ; 2.0 \mu \mathrm{L}$ of dNTP $(2.5 \mathrm{mmol} / \mathrm{L})$; and $1.5 \mathrm{U}$ of Taq polymerase (Takara). For the amplification, initial denaturation at $94^{\circ} \mathrm{C}$ for 5 minutes was followed by 30 cycles of denaturation at $94^{\circ} \mathrm{C}$ for $30 \mathrm{~s}$, annealing at $61^{\circ} \mathrm{C}$ for $30 \mathrm{~s}$, and extension at $72^{\circ} \mathrm{C}$ for $45 \mathrm{~s}$, with final extension at $72^{\circ} \mathrm{C}$ for $4 \mathrm{~min}$. Each restriction enzyme reaction was performed with $8 \mu \mathrm{L}$ of amplified DNA; $2 \mu \mathrm{L}$ of $10 \times$ buffer solution; and $0.2 \mathrm{U}$ Sst $\mathrm{I}$ restriction ezyme in a total volume of $25 \mu \mathrm{L}$ digested at $64^{\circ} \mathrm{C}$ for $4 \mathrm{~h}$. The digestive products were separated by electrophoresis on $2 \%$ sepharose gel for $60 \mathrm{~min}$. The length of each digested DNA fragment was determined by comparing migration of a sample with that of standard DNA marker. Stained with ethidium bromide, the gel was visualized under ultraviolet light and photographed. Genotypes were scored by an experienced reader blinded to epidemiological and lipid results.

\section{DNA sequencing}

Six samples (CC, CG and GG genotypes in two, respectively) detected by the PCR-RFLP were also confirmed by direct sequencing. The PCR product was purified by low melting point gel electrophoresis and phenol extraction, and then the DNA sequence were analyzed by using an ABI Prism 3100 (Applied Biosyatems) in Shanghai Sangon Biological Engineering Technology \& Services Co., Ltd., People's Republic of China.

\section{Diagnostic criteria}

The normal values of serum TC, TG, HDL-C, LDL-C, ApoA-I, and ApoB in our Clinical Science Experiment
Center were 3.10-5.17, 0.56-1.70, 1.04-1.81, 1.70-3.37 $\mathrm{mmol} / \mathrm{L}, 1.20-1.60$, and $0.63-1.14 \mathrm{~g} / \mathrm{L}$; respectively [63]. Hypertension was diagnosed according to the criteria of 1999 The World Health Organization-International Society of Hypertension Guidelines for the management of hypertension [64]. The diagnostic criteria of overweight and obesity were according to the Cooperative Meta-analysis Group of China Obesity Task Force. Normal weight, overweight and obesity were defined as a BMI $<24,24-28$, and $>28 \mathrm{~kg} / \mathrm{m}^{2}$, respectively $[63,64]$.

\section{Statistical analysis}

Epidemiological data were recorded on a pre-designed form and managed with Excel software. The quantitative variables were presented as mean \pm standard deviation (serum TG levels were presented as medians and interquartile ranges). The difference in general characteristics between nondrinkers and drinkers was tested by the Student's unpaired $t$ test. The allele frequencies of the ApoC-III $3238 \mathrm{C}>\mathrm{G}$ were determined by gene counting. A chi-square analysis was used to evaluate the allelic and genotypic frequencies that were calculated from the observed genotypic counts and to assess Hardy-Weinberg expectations. Interaction between the ApoC-III $3238 \mathrm{C}>\mathrm{G}$ genotype and alcohol consumption was assessed by using a cross-product term between genotypes and the aforementioned factor. Statistical significance was evaluated with analysis of covariance (ANCOVA). The co-variables include sex, age, BMI, hypertension, and cigarette smoking. In order to evaluate the association of serum lipid parameters with several environmental factors and genotypes, unconditional logistic regression analysis was also performed in the combined population, nondrinkers, and drinkers; respectively. The statistical analyses were performed with the statistical software package SPSS 13.0 (SPSS Inc., Chicago, Illinois). A $P$ value of less than 0.05 was considered statistically significant.

\section{Results}

General characteristics between nondrinkers and drinkers

Table 1 gives the general characteristics between the nondrinkers and drinkers. The ratio of male to female, the mean age, the levels of systolic blood pressure, diastolic blood pressure and pulse pressure, and the percentages of subjects who smoked cigarettes were higher in drinkers than in nondrinkers $(P<0.05-0.001)$. There was no significant difference in the BMI between the two groups $(P>0.05)$.

\section{Serum lipid levels between nondrinkers and drinkers}

The levels of TC, TG, HDL-C, ApoA-I and ApoB were higher in drinkers than in nondrinkers $(P<0.05-0.001)$. 
Table 1 Comparison of the general characteristics and serum lipid levels between the nondrinkers and drinkers

\begin{tabular}{|c|c|c|c|c|}
\hline Parameter & $\begin{array}{l}\text { Nondrinker } \\
(\mathrm{n}=516)\end{array}$ & $\begin{array}{c}\text { Drinker } \\
(n=514)\end{array}$ & $t\left(\chi^{2}\right)$ & $P$ \\
\hline Male/female & $186 / 330$ & $306 / 208$ & 56.930 & 0.000 \\
\hline Age (years) & $41.26 \pm 19.53$ & $45.35 \pm 15.38$ & -3.733 & 0.000 \\
\hline Body mass index $\left(\mathrm{kg} / \mathrm{m}^{2}\right)$ & $21.66 \pm 2.71$ & $21.95 \pm 2.39$ & -1.821 & 0.069 \\
\hline Systolic blood pressure $(\mathrm{mmHg})$ & $120.03 \pm 16.15$ & $125.60 \pm 15.63$ & -5.624 & 0.000 \\
\hline Diastolic blood pressure $(\mathrm{mmHg})$ & $74.13 \pm 9.82$ & $77.79 \pm 9.78$ & -5.993 & 0.000 \\
\hline Pulse pressure $(\mathrm{mmHg})$ & $45.95 \pm 11.89$ & $47.83 \pm 12.01$ & -2.525 & 0.012 \\
\hline \multicolumn{5}{|l|}{ Cigarette smoking [n(\%)] } \\
\hline Nonsmoker & $414(80.2)$ & $292(56.8)$ & & \\
\hline$<20$ cigarettes/day & $62(12.0)$ & 106(20.6) & & \\
\hline$\geq 20$ cigarettes/day & $40(7.8)$ & $116(22.6)$ & 69.628 & 0.000 \\
\hline \multicolumn{5}{|l|}{ Alcohol consumption [n(\%)] } \\
\hline Nondrinker & $516(100.0)$ & - & & \\
\hline$<25$ g/day & - & $396(77.0)$ & & \\
\hline$\geq 25 \mathrm{~g} /$ day & - & $118(23.0)$ & & \\
\hline Total cholesterol (mmol/L) & $4.52 \pm 0.99$ & $4.65 \pm 0.95$ & -2.150 & 0.032 \\
\hline Triglyceride $(\mathrm{mmol} / \mathrm{L})^{\mathrm{a}}$ & $0.97 \pm 0.57$ & $1.00 \pm 0.61$ & -2.488 & 0.013 \\
\hline $\mathrm{HDL}-\mathrm{C}(\mathrm{mmol} / \mathrm{L})$ & $1.98 \pm 0.45$ & $2.14 \pm 0.49$ & -5.458 & 0.000 \\
\hline LDL-C (mmol/L) & $2.40 \pm 0.70$ & $2.41 \pm 0.70$ & -0.229 & 0.819 \\
\hline Apolipoprotein (Apo) A-I (g/L) & $1.40 \pm 0.16$ & $1.48 \pm 0.13$ & -8.805 & 0.000 \\
\hline ApoB (g/L) & $0.89 \pm 0.22$ & $0.92 \pm 0.20$ & -2.290 & 0.022 \\
\hline ApoA-1/ApoB & $1.68 \pm 0.57$ & $1.69 \pm 0.46$ & -0.310 & 0.757 \\
\hline
\end{tabular}

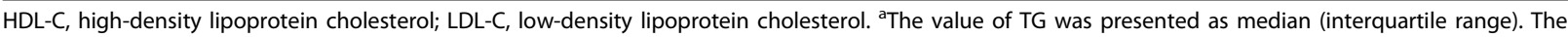
difference between the two ethnic groups was determined by the Wilcoxon-Mann-Whitney test.

There were no significant differences in the levels of LDL-C and the ratio of ApoA-I to ApoB between the two groups $(P>0.05$ for each).

\section{Results of electrophoresis and genotyping}

After the genomic DNA of the samples was amplified by PCR and imaged by $2 \%$ agarose gel electrophoresis, the purpose gene of 596 bp nucleotide sequences could be seen in the samples (Figure 1). The genotypes identified were named according to the presence or absence of the enzyme restriction sites, when a $C$ to $G$ transversion at nucleotide position 3238 of the ApoC-III gene. The presence of the cutting site indicates the $3238 \mathrm{G}$ allele, while its absence indicates the $3238 \mathrm{C}$ allele. Thus, the GG genotype is homozygote for the presence of the site (bands at $371 \mathrm{bp}$ and $225 \mathrm{bp}$ ), CG genotype is heterozygote for the presence and absence of the site (bands at $596 \mathrm{bp}, 371 \mathrm{bp}$ and $225 \mathrm{bp}$ ), and CC genotype is homozygote for the absence of the site (band 596 bp; Figure $1)$. The genotype distribution was consistent with the Hardy-Weinberg equilibrium.

\section{Results of sequencing}

The results shown as CC, CG and GG genotypes by PCR-RFLP, CC, CG and GG genotypes were also confirmed by sequencing (Figure 2).

\section{Genotypic and allelic frequencies}

The genotypic and allelic frequencies of the ApoC-III $3238 \mathrm{C}>\mathrm{G}$ are shown in Table 2. The frequencies of $\mathrm{CC}$, CG and GG genotypes were $45.7 \%, 43.0 \%$ and $11.3 \%$ in nondrinkers, and $45.2 \%, 45.5 \%$ and $9.3 \%$ in drinkers $(P>0.05)$; respectively. The frequencies of $\mathrm{C}$ and $\mathrm{G}$ alleles were $67.2 \%$ and $32.8 \%$ in nondrinkers, and $67.9 \%$ and $32.1 \%$ in drinkers $(P>0.05)$; respectively.

\section{Genotypes and serum lipid levels}

As shown in Table 3, the levels of TG in nondrinkers were higher in CG genotype than in CC genotype $(P<$ 0.01 ), and the ratio of ApoA-I to ApoB in nondrinkers was higher in GG genotype than in CG genotype $(P<$ 0.05).

The levels of TC, TG, LDL-C and ApoB in drinkers were higher in GG genotype than in CC or CG genotype $(P<0.01$ for all). The levels of HDL-C in drinkers were higher in CG genotype than in CC genotype $(P<$ 0.01). The ratio of ApoA-I to ApoB in drinkers was lower in GG genotype than in CC or CG genotype $(P<$ 0.01 for each).

Serum TC, TG, HDL-C and ApoA-I levels in CC genotype, TC, HDL-C, ApoA-I levels and the ratio of ApoA-I to ApoB in CG genotype, and TC, TG, LDL-C, ApoA-I and ApoB levels in GG genotype were higher in 


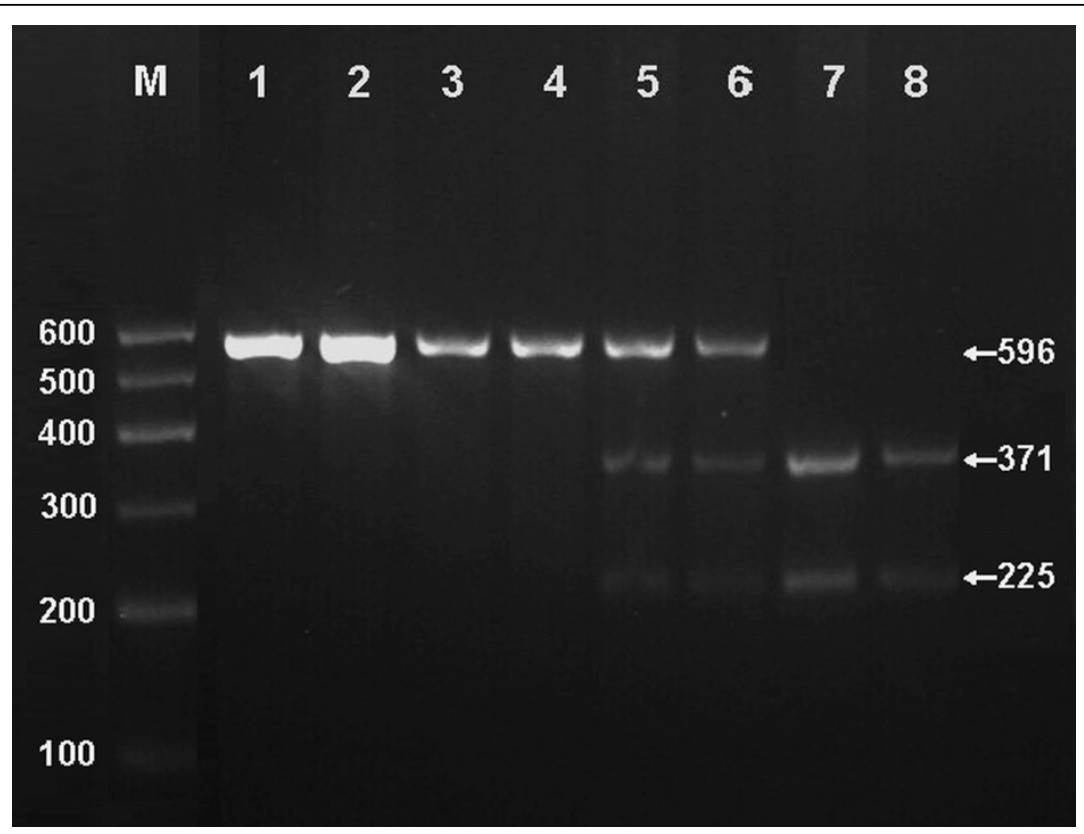

Figure 1 Genotyping of PCR products of the samples. Lane M, 100 bp Marker Ladder; Lanes 1 and 2, the PCR products of the samples (596 bp); Lane 3 and 4, CC genotype (596 bp); Lanes 5 and 6, CG genotype (596 bp, 371 bp and 225 bp); and lanes 7 and 8, GG genotype (371 bp and $225 \mathrm{bp}$ ).

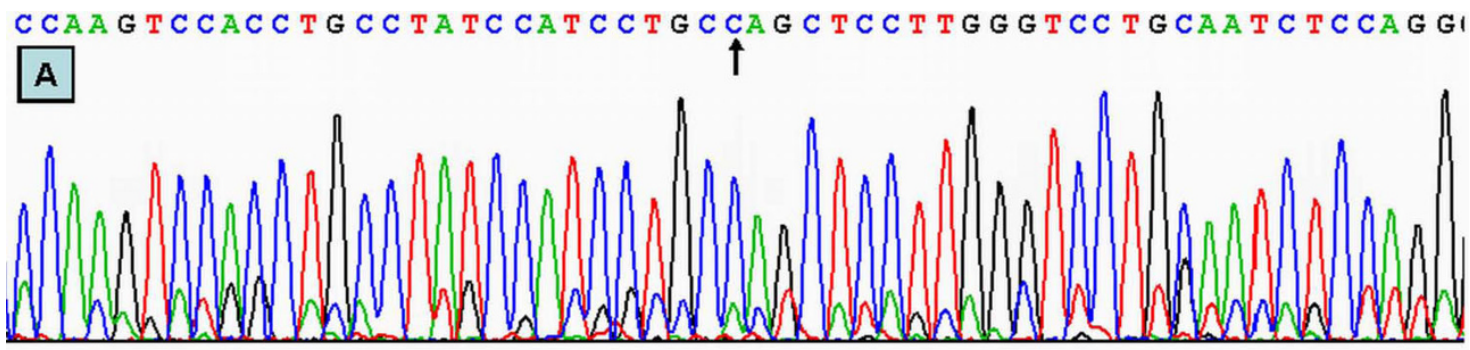

C CAAG TC CAC C T G C C T A T C C ATC C T G CNAGC TC C T T G G G T C T G CAATC TC CA G G

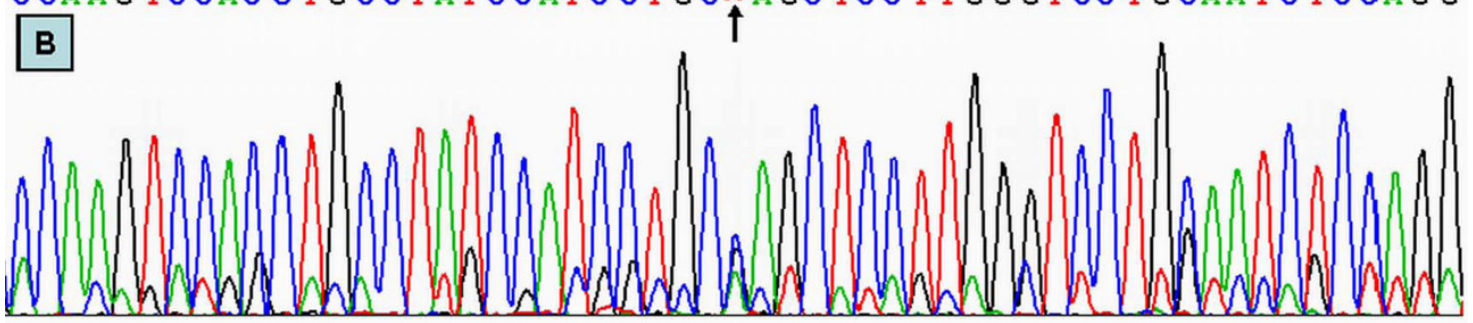

C CAA G T C A C C T G C T A T C C $\uparrow$

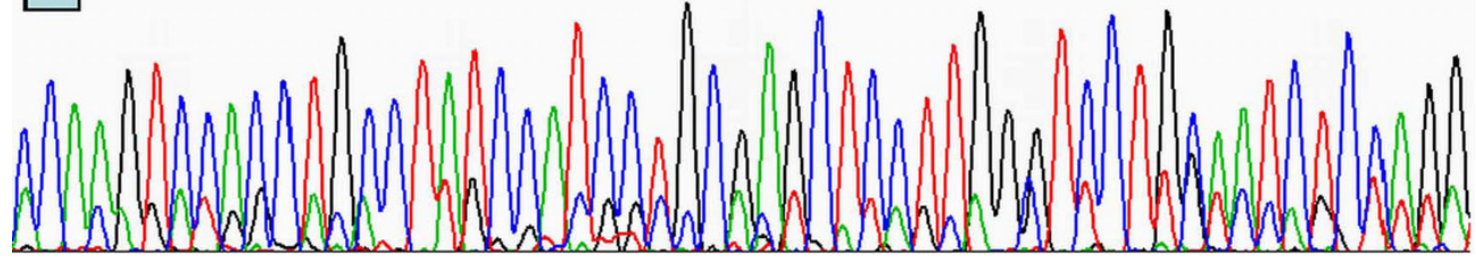

Figure 2 A part of the nucleotide sequence of the ApoC-III 3238C >G. (A) CC genotype; (B) CG genotype; (C) GG genotype. 
Table 2 Genotypic and allelic frequencies between the nondrinkers and drinkers [n (\%)]

\begin{tabular}{lcccccc}
\hline Group & $\boldsymbol{n}$ & \multicolumn{3}{c}{ Genotype } & \multicolumn{2}{c}{ Allele } \\
\cline { 3 - 7 } & & CC & CG & GG & C & G \\
\hline Nondrinker & 516 & $236(45.7)$ & $222(43.0)$ & $58(11.3)$ & $694(67.2)$ & $338(32.8)$ \\
Drinker & 514 & $232(45.2)$ & $234(45.5)$ & $48(9.3)$ & $698(67.9)$ & $330(32.1)$ \\
$\chi^{2}$ & - & & 1.290 & & 0.010 \\
$P$ & - & & 0.525 & & \multicolumn{2}{c}{0.752} \\
\hline
\end{tabular}

drinkers than in nondrinkers $(P<0.05-0.01)$. But the ratio of ApoA-I to ApoB in GG genotype was lower in drinkers than in nondrinkers $(P<0.01)$.

\section{Correlation between genotype and serum lipid parameters}

Multivariate logistic regression analysis showed that the levels of TC, TG LDL-C and ApoA-I were correlated with genotype in the combined population $(P<0.05$ 0.01). The levels of TC, TG and ApoB were correlated with genotype in nondrinkers $(P<0.05$ for all $)$. The levels of TC, LDL-C and ApoB were associated with genotype in drinkers $(P<0.01$ for all). Serum lipid parameters were also correlated with age, sex, alcohol consumption, cigarette smoking, blood pressure, body weight, and BMI in both nondrinkers and drinkers (Table 4).

\section{Discussion}

The results of the present study show that the levels of TC, TG, HDL-C, ApoA-I and ApoB were higher in drinkers than in nondrinkers. There was no significant difference in the levels of LDL-C and the ratio of ApoAI to ApoB between the two groups. These findings are consistent with those of several previous studies. A moderate intake of alcohol is associated with protection against $\mathrm{CAD}$, probably due in part to a dose-dependent increase in HDL-C $[65,66]$. According to Rimma et al. [67], a daily dose of $30 \mathrm{~g}$ alcohol results in an average HDL level rise of $3.99 \mathrm{mg} / \mathrm{dl}$, and an ApoA-I level rise of $8.82 \mathrm{mg} / \mathrm{dl}$. Alcohol also causes an increase of TG lipase activity and a decrease of the HDL removal from the circulation [68]. A decrease in LDL-C with increased alcohol intake has also been reported in some studies, but this effect is less consistent and probably depends on the combination of one or more unmeasured factors [68].

The present study shows that there was no significant difference in the allelic and genotypic frequencies of the ApoC-III 3238C > G between the nondrinkers and drinkers. The frequency of $\mathrm{G}$ allele was $32.8 \%$ in nondrinkers, and $32.1 \%$ in drinkers, which is quite similar to the results in Taiwanese (0.30-0.43) [46,69], Japanese $(0.25$ 0.48) [70], and Indians (0.36) [27], but is higher than those reported for Caucasians in whom the $\mathrm{G}$ allele frequency was $0.00-0.11[27,55]$. These results suggest that there exists significant racial variation of allele frequencies in this locus.

The relationship between the ApoC-III 3238C $>$ G polymorphism and plasma or serum lipid levels in humans has been evaluated in a large number of studies. However, previous findings on the association of this polymorphism with the changes in plasma lipid levels are inconsistent [71-73]. Previous cohort studies, as well as case-control and familial studies have shown significant association between the rare allele of the polymorphic SstI site (3238G) and higher plasma TG levels [16-53] and CAD [53-62]. This association has been reported in studies carried out with Caucasians, Chinese, Mayans, Japanese (living in Japan or living in Southern Brazil), Koreans, Arabs, and Asian Indians [27,49,55,69,70]. However, several reports failed to find a significant

Table 3 Comparison of serum lipid levels among the genotypes and between the nondrinkers and drinkers

\begin{tabular}{|c|c|c|c|c|c|c|c|c|c|}
\hline Group & Genotype & $n$ & $\begin{array}{c}\mathrm{TC} \\
(\mathrm{mmol} / \mathrm{L})\end{array}$ & $\begin{array}{c}\text { TG } \\
(\mathrm{mmol} / \mathrm{L})\end{array}$ & $\begin{array}{c}\mathrm{HDL}-\mathrm{C} \\
(\mathrm{mmol} / \mathrm{L})\end{array}$ & $\begin{array}{c}\text { LDL-C } \\
(\mathrm{mmol} / \mathrm{L})\end{array}$ & $\begin{array}{c}\text { ApoA-I } \\
(\mathrm{g} / \mathrm{L})\end{array}$ & $\begin{array}{c}\text { ApoB } \\
(\mathrm{g} / \mathrm{L})\end{array}$ & $\begin{array}{c}\text { AроA-I/ } \\
\text { АроB }\end{array}$ \\
\hline \multirow[t]{3}{*}{ Nondrinker } & CC & 236 & $4.49 \pm 0.88$ & $0.91 \pm 0.57$ & $1.97 \pm 0.42$ & $2.41 \pm 0.69$ & $1.40 \pm 0.13$ & $0.89 \pm 0.21$ & $1.70 \pm 0.64$ \\
\hline & $C G$ & 222 & $4.53 \pm 1.11$ & $1.01 \pm 0.59^{b}$ & $1.98 \pm 0.48$ & $2.40 \pm 0.68$ & $1.40 \pm 0.18$ & $0.91 \pm 0.22$ & $1.62 \pm 0.41$ \\
\hline & GG & 58 & $4.57 \pm 1.03$ & $0.93 \pm 0.60$ & $2.01 \pm 0.43$ & $2.40 \pm 0.83$ & $1.42 \pm 0.12$ & $0.86 \pm 0.28$ & $1.84 \pm 0.75^{c}$ \\
\hline$F$ & - & - & 0.186 & 12.517 & 0.187 & 0.013 & 0.445 & 1.275 & 3.685 \\
\hline$P$ & - & - & 0.830 & 0.002 & 0.829 & 0.987 & 0.641 & 0.280 & 0.026 \\
\hline \multirow[t]{3}{*}{ Drinker } & $\mathrm{CC}$ & 232 & $4.72 \pm 0.90^{* *}$ & $0.97 \pm 0.63^{* *}$ & $2.07 \pm 0.45^{*}$ & $2.38 \pm 0.71$ & $1.47 \pm 0.14^{* *}$ & $0.91 \pm 0.20$ & $1.70 \pm 0.46$ \\
\hline & $C G$ & 234 & $4.75 \pm 0.86^{*}$ & $0.95 \pm 0.54$ & $2.23 \pm 0.53^{b * *}$ & $2.37 \pm 0.66$ & $1.49 \pm 0.13^{* *}$ & $0.91 \pm 0.20$ & $1.73 \pm 0.47^{* *}$ \\
\hline & GG & 48 & $5.29 \pm 0.91^{b d * *}$ & $1.28 \pm 0.93^{b d * *}$ & $2.12 \pm 0.49$ & $2.77 \pm 0.72^{\mathrm{bd} *}$ & $1.49 \pm 0.14^{* *}$ & $1.06 \pm 0.18^{b d * *}$ & $1.44 \pm 0.30^{\mathrm{bd} * *}$ \\
\hline$F$ & - & - & 8.662 & 18.352 & 6.253 & 7.173 & 1.382 & 12.457 & 8.300 \\
\hline$P$ & - & - & 0.000 & 0.000 & 0.002 & 0.000 & 0.252 & 0.000 & 0.000 \\
\hline
\end{tabular}

TC, total cholesterol; TG, triglyceride; HDL-C, high-density lipoprotein cholesterol; LDL-C, low-density lipoprotein cholesterol; ApoA-I, apolipoprotein A-I; ApoB, apolipoprotein B. The value of TG was presented as median (interquartile range). The difference among the genotypes was determined by the Kruskal-Wallis test. ${ }^{a} P<0.05$ and ${ }^{b} P<0.01$ in comparison with CC genotype of the same subgroup; ${ }^{C} P<0.05$ and ${ }^{d} P<0.01$ in comparison with CG genotype of the same subgroup; ${ }^{*} P<0.05$ and ${ }^{* *} P<0.01$ in comparison with the same subgroup of the nondrinkers. 
Table 4 Correlative factors for the serum lipid parameters between the nondrinkers and drinkers

\begin{tabular}{|c|c|c|c|c|c|}
\hline Lipid parameter & Risk factor & Odds ratio & $\chi^{2}$ & $P$ & $95 \% \mathrm{Cl}$ \\
\hline \multicolumn{6}{|c|}{ Nondrinkers plus drinkers } \\
\hline \multirow[t]{3}{*}{ TC } & Age & 1.030 & 45.053 & 0.000 & $1.021-1.039$ \\
\hline & Body mass index & 1.144 & 22.000 & 0.000 & $1.081-1.210$ \\
\hline & ApoC-III 3238C $>$ G genotype & 1.324 & 6.542 & 0.011 & $1.068-1.642$ \\
\hline \multirow[t]{5}{*}{ TG } & Body mass index & 1.223 & 30.735 & 0.000 & $1.139-1.314$ \\
\hline & Pulse pressure & 1.018 & 5.255 & 0.022 & $1.003-1.034$ \\
\hline & Alcohol consumption & 1.744 & 14.249 & 0.000 & $1.307-2.329$ \\
\hline & Cigarette smoking & 0.614 & 4.056 & 0.044 & $0.382-0.987$ \\
\hline & ApoC-III 3238C>G genotype & 1.517 & 8.448 & 0.004 & $1.145-2.009$ \\
\hline \multirow[t]{5}{*}{ LDL-C } & Age & 1.030 & 14.365 & 0.000 & $1.014-1.046$ \\
\hline & Sex & 1.898 & 5.549 & 0.018 & $1.114-3.236$ \\
\hline & Body weight & 1.107 & 43.419 & 0.000 & $1.074-1.141$ \\
\hline & Alcohol consumption & 0.704 & 4.248 & 0.039 & $0.504-0.983$ \\
\hline & ApoC-III 3238C>G genotype & 1.709 & 9.600 & 0.002 & $1.218-2.400$ \\
\hline \multirow[t]{4}{*}{ ApoA-I } & Age & 0.745 & 12.294 & 0.000 & $0.632-0.878$ \\
\hline & Sex & 0.414 & 9.812 & 0.002 & $0.238-0.719$ \\
\hline & Pulse pressure & 0.974 & 4.009 & 0.045 & 0.949-0.999 \\
\hline & Alcohol consumption & 0.327 & 12.749 & 0.000 & $0.177-0.604$ \\
\hline \multirow[t]{5}{*}{ ApoB } & Age & 1.036 & 38.386 & 0.000 & $1.025-1.048$ \\
\hline & Body weight & 1.086 & 45.102 & 0.000 & $1.060-1.113$ \\
\hline & Alcohol consumption & 3.154 & 7.351 & 0.007 & $1.375-7.234$ \\
\hline & ApoC-III 3238C>G genotype & 1.678 & 15.923 & 0.000 & $1.301-2.163$ \\
\hline & Sex & 1.678 & 3.923 & 0.048 & $1.004-2.219$ \\
\hline \multicolumn{6}{|l|}{ Nondrinkers } \\
\hline \multirow[t]{4}{*}{$\mathrm{TC}$} & Age & 1.142 & 13.511 & 0.000 & $1.064-1.225$ \\
\hline & Body mass index & 1.175 & 14.633 & 0.000 & $1.082-1.277$ \\
\hline & ApoC-III 3238C>G genotype & 1.324 & 6.542 & 0.011 & $1.068-1.642$ \\
\hline & Cigarette smoking & 0.639 & 4.668 & 0.031 & $0.425-0.959$ \\
\hline \multirow[t]{4}{*}{ TG } & Body mass index & 1.163 & 7.954 & 0.005 & $1.047-1.292$ \\
\hline & Age & 1.314 & 9.279 & 0.002 & $1.102-1.566$ \\
\hline & Cigarette smoking & 0.280 & 5.302 & 0.021 & $0.095-0.827$ \\
\hline & ApoC-III 3238C>G genotype & 2.200 & 12.048 & 0.044 & $1.410-3.434$ \\
\hline \multirow[t]{3}{*}{ LDL-C } & Age & 1.039 & 13.847 & 0.000 & $1.018-1.060$ \\
\hline & Body weight & 1.131 & 34.897 & 0.000 & $1.086-1.178$ \\
\hline & Sex & 3.379 & 9.542 & 0.002 & $1.561-7.317$ \\
\hline \multirow[t]{4}{*}{ ApoA-I } & Body weight & 1.061 & 4.339 & 0.037 & $1.004-1.122$ \\
\hline & Body mass index & 0.671 & 14.044 & 0.000 & $0.545-0.827$ \\
\hline & Age & 0.733 & 11.783 & 0.001 & $0.614-0.875$ \\
\hline & Cigarette smoking & 1.667 & 4.219 & 0.040 & $1.024-2.713$ \\
\hline \multirow[t]{3}{*}{ ApoB } & Age & 1.143 & 11.084 & 0.001 & $1.057-1.237$ \\
\hline & Body weight & 1.084 & 25.440 & 0.000 & $1.051-1.119$ \\
\hline & ApoC-III 3238C>G genotype & 1.574 & 6.223 & 0.013 & $1.102-2.248$ \\
\hline \multicolumn{6}{|l|}{ Drinkers } \\
\hline \multirow[t]{3}{*}{$\mathrm{TC}$} & Age & 1.326 & 15.892 & 0.000 & $1.154-1.523$ \\
\hline & Body weight & 1.052 & 12.961 & 0.000 & $1.023-1.082$ \\
\hline & ApoC-III 3238C>G genotype & 1.874 & 16.157 & 0.000 & $1.380-2.545$ \\
\hline \multirow[t]{2}{*}{ TG } & Alcohol consumption & 0.674 & 10.599 & 0.001 & $0.532-0.855$ \\
\hline & Body mass index & 1.270 & 23.776 & 0.000 & $1.154-1.399$ \\
\hline \multirow[t]{2}{*}{ LDL-C } & Height & 1.063 & 7.372 & 0.007 & $1.017-1.112$ \\
\hline & ApoC-III 3238C $>$ G genotype & 2.319 & 10.577 & 0.001 & $1.397-3.849$ \\
\hline \multirow[t]{2}{*}{ ApoA-I } & Body weight & 1.078 & 6.384 & 0.037 & $1.017-1.143$ \\
\hline & Systolic blood pressure & 0.942 & 7.787 & 0.005 & 0.903-0.982 \\
\hline
\end{tabular}


Table 4 Correlative factors for the serum lipid parameters between the nondrinkers and drinkers (Continued)

\begin{tabular}{llllll}
\hline ApoB & Age & 1.040 & 17.141 & 0.000 & $1.021-1.060$ \\
& Body weight & 1.084 & 22.706 & 0.000 & $1.049-1.121$ \\
& Pulse pressure & 0.974 & 5.365 & 0.021 & $0.952-0.996$ \\
Alcohol consumption & 0.360 & 13.214 & 0.000 & $0.207-0.624$ \\
& ApoC-III 3238C $>$ G genotype & 1.863 & 11.039 & 0.001 & $1.291-2.689$ \\
\hline
\end{tabular}

TC, total cholesterol; TG, triglyceride; LDL-C, low-density lipoprotein cholesterol; ApoA-I, apolipoprotein A-I; ApoB, apolipoprotein B; Cl, confidence interval

genetic effect on TG concentrations [71-73]. In a previous work, Kee and coworkers found no association between variability at the Sst I ApoC-III gene site (in the $3 \%$-noncoding region) and lipid, lipoproteins and complex lipoprotein particles in a sample of men from northern France [72]. They thought that the SstI polymorphism is not major contributors to the risk of dyslipidemia in the population of northern France. Results from the current study are consistent with many studies cited above which reported associations of ApoC-III gene polymorphism with altered lipid metabolism. The levels of TG in nondrinkers were higher in CG genotype than in CC genotype, and the ratio of ApoA-I to ApoB in nondrinkers was higher in GG genotype than in $C G$ genotype. The levels of TC, TG, LDL-C and ApoB in drinkers were higher in $G G$ genotype than in $C C$ or $C G$ genotype. The levels of HDL-C in drinkers were higher in $C G$ genotype than in $C C$ genotype. The ratio of ApoA-I to ApoB in drinkers was lower in GG genotype than in $C C$ or CG genotype.

The interactions of the ApoC-III 3238C $>$ G polymorphism and alcohol consumption on serum lipid levels are not well known. In the present study, we showed that serum TC, TG, HDL-C and ApoA-I levels in $\mathrm{CC}$ genotype, TC, HDL-C, ApoA-I levels and the ratio of ApoA-I to ApoB in CG genotype, and TC, TG, LDL-C, ApoA-I and ApoB levels in GG genotype were higher in drinkers than in nondrinkers. But the ratio of ApoA-I to ApoB in GG genotype was lower in drinkers than in nondrinkers. The levels of TG were correlated with genotype in nondrinkers, whereas the levels of TG were positively associated with alcohol consumption in drinkers. These findings suggest that the ApoC-III 3238CG heterozygotes benefited more from alcohol consumption than CC and GG homozygotes in increasing serum levels of HDL-C, ApoA-I, and the ratio of ApoA-I to ApoB, and lowering serum levels of TC and TG. The effect of different kinds of wine on the lipid profiles is not well known. In a previous study, Ruidavets et al. [74] found that wine was positively associated with HDL-C. Beer was positively associated with HDL-C in men and with TGs in men and women. When taking drinking patterns into account, wine drinkers had higher HDL-C levels than non-wine drinkers. In another study, Choudhury et al. [75] also showed serum TGs levels were significantly lower in those who drank beer. Thus, we hypothesize that the interactions between the ApoCIII $3238 C>G$ polymorphism and different kinds of alcoholic beverage on serum lipid levels may be different.

\section{Conclusion}

The results of the present study show that there was no significant difference in genotypic and allelic frequencies of the ApoC-III 3238C >G polymorphism between the nondrinkers and drinkers. But the interactions of the ApoC-III 3238C $>$ G polymorphism and alcohol consumption on serum lipid levels are different among the three genotypes. The ApoC-III 3238CG heterozygotes benefited more from alcohol consumption than $\mathrm{CC}$ and GG homozygotes in increasing serum levels of HDL-C, ApoA-I, and the ratio of ApoA-I to ApoB, and lowering serum levels of TC and TG.

\section{Acknowledgements}

This study was supported by the National Natural Science Foundation of China (No. 30360038).

\section{Author details}

${ }^{1}$ Department of Cardiology, Institute of Cardiovascular Diseases, the First Affiliated Hospital, 22 Shuangyong Road, Nanning 530021, Guangxi, People's Republic of China. ${ }^{2}$ Department of Molecular Biology, Medical Scientific Research Center, 22 Shuangyong Road, Nanning 530021, Guangxi, People's Republic of China.

\section{Authors' contributions}

YR and LY conceived the study, participated in the design, carried out the epidemiological survey, collected the samples, performed the statistical analyses, and drafted the manuscript; LM, LK, LX, ZL and LW carried out the biochemical analysis; WJ, YD and LW carried out the epidemiological survey, collected the samples, and helped to carry out the genotyping. All authors read and approved the final manuscript.

\section{Competing interests}

The authors declare that they have no competing interests.

Received: 6 July 2010 Accepted: 17 August 2010

Published: 17 August 2010

\section{References}

1. Austin MA: Plasma triglyceride as a risk factor for coronary heart disease. The epidemiologic evidence and beyond. Am J Epidemiol 1989, 129:249-59.

2. Hokanson JE, Austin MA: Plasma triglyceride level is a risk factor for cardiovascular disease independent of high-density lipoprotein cholesterol level: a meta-analysis of population-based prospective studies. J Cardiovasc Risk 1996, 3:213-9.

3. Talmud PJ, Hawe E, Miller GJ, Humphries SE: Nonfasting apolipoprotein B and triglyceride levels as a useful predictor of coronary heart disease 
risk in middle-aged UK men. Arterioscler Thromb Vasc Biol 2002, 22:1918-23.

4. Arai H, Yamamoto A, Matsuzawa Y, Saito Y, Yamada N, Oikawa S, Mabuchi H, Teramoto T, Sasaki J, Nakaya N, Itakura H, Ishikawa Y, Ouchi Y, Horibe $\mathrm{H}$ : Serum lipid survey and its recent trend in the general Japanese population in 2000. J Atheroscler Thromb 2005, 12:98-106.

5. Satoh $\mathrm{H}$, Nishino $\mathrm{T}$, Tomita $\mathrm{K}$, Tsutsui $\mathrm{H}$ : Fasting triglyceride is a significant risk factor for coronary artery disease in middle-aged Japanese men: Results from a 10-year cohort study. Circ J 2006, 70:227-31.

6. Wu LL: Review of risk factors for cardiovascular diseases. Ann Clin Lab Sci 1999, 29:127-33

7. You M, Crabb DW: Recent advances in alcoholic liver disease II. Minireview: molecular mechanisms of alcoholic fatty liver. Am J Physiol Gastrointest Liver Physiol 2004, 287:G1-G6.

8. Castelli WP, Doyle JT, Gordon T, Hames CG, Hjortland MC, Hulley SB, Kagan A, Zukel WJ: Alcohol and blood lipids. The cooperative lipoprotein phenotyping study. Lancet 1977, 2:153-5.

9. Ruixing $Y$, Shangling $P$, Hong $C$, Hanjun $Y$, Hai W, Yuming $C$, Jinzhen $W$, Feng $H$, Meng L, Muyan L: Diet, alcohol consumption, and serum lipid levels of the middle-aged and elderly in the Guangxi Bai Ku Yao and Han populations. Alcohol 2008, 42:219-29.

10. Stampfer MJ, Krauss RM, Ma J, Blanche PJ, Holl LG, Sacks FM, Hennekens $\mathrm{CH}$ : A prospective study of trigliceryde level, low-density lipoprotein particle diameter, and risk of myocardial infarction. JAMA 1996, 276:882-8

11. Wang C, McConathy WJ, Kloer HU, Alaupovic P: Modulation of lipoprotein lipase activity by apolipoproteins. J Clin Invest 1985, 75:384-90.

12. Le NA, Gibson JC, Ginsberg HN: Independent regulation of plasma apolipoprotein C-II and C-III concentrations in very low density and high density lipoproteins: implications for the regulation of the catabolism of these lipoproteins. J Lipid Res 1988, 29:669-77.

13. Ito Y, Azrolan N, O'Connell A, Walsh A, Breslow JL: Hypertriglyceridemia as a result of human apo CIII gene expression in transgenic mice. Science 1990, 249:790-3.

14. Bruns GA, Karanthasis SK, Breslow JL: Human apolipoprotein Al-CIII gene complex is located on chromosome 11. Arteriosclerosis 1984, 4:97-102.

15. Talmud PJ, Humphries SE: Apolipoprotein C-III gene variation and dyslipidaemia. Curr Opin Lipidol 1997, 8:154-8.

16. Hegele RA, Connelly PW, Hanley AJ, Sun F, Harris SB, Zinman B: Common genomic variation in the APOC3 promoter associated with variation in plasma lipoproteins. Arterioscler Thromb Vasc Biol 1997, 17:2753-8.

17. Ordovas JM, Civeira F, Genest J Jr, Craig S, Robbins AH, Meade T, Pocovi M, Frossard PM, Masharani U, Wilson PW: Restriction fragment length polymorphisms of the apolipoprotein A-I, C-III, A-IV gene locus. Relationships with lipids, apolipoproteins, and premature coronary artery disease. Atherosclerosis 1991, 87:75-86.

18. Rees A, Stocks J, Paul H, Ohuchi Y, Galton D: Haplotypes identified by DNA polymorphisms at the apolipoprotein A-1 and C-III loci and hypertriglyceridaemia. A study in a Japanese population. Hum Genet 1986, 72:168-71.

19. Hong SH, Park WH, Lee CC, Song JH, Kim JQ: Association between genetic variations of apo Al-CIII-AIV cluster gene and hypertriglyceridemic subjects. Clin Chem 1997, 43:13-7.

20. Ferrell RE, Kamboh Ml, Majumder PP, Valdez R, Weiss KM: Genetic studies of human apolipoproteins. XIII. Quantitative polymorphism of apolipoprotein C-III in the Mayans of the Yucatan Peninsula. Hum Hered 1990, 40:127-35

21. Dallongeville J, Meirhaeghe A, Cottel D, Fruchart JC, Amouyel P, Helbecque N: Gender related association between genetic variations of APOC-III gene and lipid and lipoprotein variables in northern France. Atherosclerosis 2000, 150:149-57.

22. Wu JH, Kao JT, Wen MS, Lo SK: DNA polymorphisms at the apolipoprotein A1-CIII loci in Taiwanese: correlation of plasma APOCIII with triglyceride level and body mass index. J Formos Med Assoc 2000, 99:367-74.

23. Waterworth DM, Talmud PJ, Bujac SR, Fisher RM, Miller GJ, Humphries SE: Contribution of apolipoprotein C-III gene variants to determination of triglyceride levels and interaction with smoking in middle-aged men. Arterioscler Thromb Vasc Biol 2000, 20:2663-9.

24. Waterworth DM, Talmud PJ, Humphries SE, Wicks PD, Sagnella GA, Strazzullo P, Alberti KG, Cook DG, Cappuccio FP: Variable effects of the
APOC3-482C > T variant on insulin, glucose and triglyceride concentrations in different ethnic groups. Diabetologia 2001, 44:245-8.

25. Buzza M, Fripp Y, Mitchell RJ: Apolipoprotein Al and CIII gene polymorphisms and their association with lipid levels in Italian, Greek and Anglo-Irish populations of Australia. Ann Hum Biol 2001, 28:481-90.

26. Corella D, Guillén M, Sáiz C, Portolés O, Sabater A, Folch J, Ordovas JM: Associations of LPL and APOC3 gene polymorphisms on plasma lipids in a Mediterranean population: interaction with tobacco smoking and the APOE locus. J Lipid Res 2002, 43:416-27.

27. Chhabra S, Narang R, Krishnan LR, Vasisht S, Agarwal DP, Srivastava LM, Manchanda SC, Das N: Apolipoprotein C3 Sstl polymorphism and triglyceride levels in Asian Indians. BMC Genet 2002, 3:9.

28. Rodrigo E, González-Lamuño D, Ruiz JC, Fernández-Fresnedo G, Isla D, González-Cotorruelo J, Zubimendi JA, De Francisco AL, García-Fuentes M, Arias M: Apolipoprotein C-III and E polymorphisms and cardiovascular syndrome, hyperlipidemia, and insulin resistance in renal transplantation. Am J Transplant 2002, 2:343-8.

29. Minihane AM, Finnegan YE, Talmud P, Leigh-Firbank EC, Williams CM: Influence of the APOC3 -2854T>G polymorphism on plasma lipid levels: effect of age and gender. Biochim Biophys Acta 2002, 1583:311-4.

30. Humphries SE, Berglund L, Isasi CR, Otvos JD, Kaluski D, Deckelbaum RJ, Shea S, Talmud PJ: Loci for CETP, LPL, LIPC, and APOC3 affect plasma lipoprotein size and sub-population distribution in Hispanic and nonHispanic white subjects: the Columbia University BioMarkers Study. Nutr Metab Cardiovasc Dis 2002, 12:163-72.

31. Couillard C, Vohl MC, Engert JC, Lemieux I, Houde A, Almeras N, Prud'homme D, Nadeau A, Despres JP, Bergeron J: Effect of apoC-III gene polymorphisms on the lipoprotein-lipid profile of viscerally obese men. $J$ Lipid Res 2003, 44:986-93.

32. Espino-Montoro A, Barrios-Artillo M, López-Chozas JM, Cayuela A, Stiefel P, Villar J: Influence of polymorphism (RFLP-sstl) at the apolipoprotein C-III gene locus on the lipoprotein metabolism and insulin resistance in essential hypertensive patients. Interaction between gender and genetic polymorphism. Nutr Metab Cardiovasc Dis 2003, 13:194-201.

33. Surguchov AP, Page GP, Smith L, Patsch W, Boerwinkle E: Polymorphic markers in apolipoprotein C-III gene flanking regions and hypertriglyceridemia. Arterioscler Thromb Vasc Biol 1996, 16:941-7.

34. Li GP, Wang JY, Yan SK, Chen BS, Xue H, Wu G: Genetic effect of two polymorphisms in the apolipoprotein A5 gene and apolipoprotein C3 gene on serum lipids and lipoproteins levels in a Chinese population. Clin Genet 2004, 65:470-6.

35. Garenc C, Aubert S, Laroche J, Girouard J, Vohl MC, Bergeron J, Rousseau F, Julien P: Population prevalence of APOE, APOC3 and PPAR-alpha mutations associated to hypertriglyceridemia in French Canadians. $J$ Hum Genet 2004, 49.691-700.

36. Guettier JM, Georgopoulos A, Tsai MY, Radha V, Shanthirani S, Deepa R, Gross M, Rao G, Mohan V: Polymorphisms in the fatty acid-binding protein 2 and apolipoprotein C-III genes are associated with the metabolic syndrome and dyslipidemia in a South Indian population. J Clin Endocrinol Metab 2005, 90:1705-11.

37. Garenc C, Couillard C, Laflamme N, Cadelis F, Gagné C, Couture P, Julien P, Bergeron J: Effect of the APOC3 Sst I SNP on fasting triglyceride levels in men heterozygous for the LPL P207L deficiency. Eur J Hum Genet 2005, 13:1159-65.

38. Ruiz-Narváez EA, Yang Y, Nakanishi Y, Kirchdorfer J, Campos H: APOC3/A5 haplotypes, lipid levels, and risk of myocardial infarction in the Central Valley of Costa Rica. J Lipid Res 2005, 46:2605-13.

39. Herron $\mathrm{KL}$, Lofgren IE, Adiconis $\mathrm{X}$, Ordovas JM, Fernandez ML: Associations between plasma lipid parameters and APOC3 and APOA4 genotypes in a healthy population are independent of dietary cholesterol intake. Atherosclerosis 2006, 184:113-20.

40. Huang MC, Wang TN, Liu YL, Pa TH, Tu HP, Huang YC, Chang WT, Ko YC: Effect of Sstl polymorphism of the apolipoprotein CIII gene and environmental factors on risks of hypertriglyceridemia in Taiwan aborigines. Circ J 2006, 70:1030-6.

41. Hallman DM, Srinivasan SR, Chen W, Boerwinkle E, Berenson GS Longitudinal analysis of haplotypes and polymorphisms of the APOA5 and APOC3 genes associated with variation in serum triglyceride levels: the Bogalusa Heart Study. Metabolism 2006, 55:1574-81.

42. Dorfmeister B, Cooper JA, Stephens JW, Ireland H, Hurel SJ, Humphries SE, Talmud PJ: The effect of APOA5 and APOC3 variants on lipid parameters 
in European Whites, Indian Asians and Afro-Caribbeans with type 2 diabetes. Biochim Biophys Acta 2007, 1772:355-63.

43. Fiegenbaum M, de Andrade FM, Hutz MH: Association between plasma lipid parameters and APOC3 genotypes in Brazilian subjects: effect of gender, smoking and APOE genotypes. Clin Chim Acta 2007, 380:175-81.

44. Miller M, Rhyne J, Chen H, Beach V, Ericson R, Luthra K, Dwivedi M, Misra A: APOC3 promoter polymorphisms C-482T and T-455C are associated with the metabolic syndrome. Arch Med Res 2007, 38:444-51.

45. Pollex RL, Ban MR, Young TK, Bjerregaard P, Anand SS, Yusuf S, Zinman B, Harris SB, Hanley AJ, Connelly PW, Huff MW, Hegele RA: Association between the $-455 \mathrm{~T}>\mathrm{C}$ promoter polymorphism of the APOC3 gene and the metabolic syndrome in a multi-ethnic sample. BMC Med Genet 2007, 8:80.

46. Chien KL, Fang WH, Wen HC, Lin HP, Lin YL, Lin SW, Wu JH, Kao JT: APOA1/C3/A5 haplotype and risk of hypertriglyceridemia in Taiwanese. Clin Chim Acta 2008, 390:56-62

47. Bonnet E, Bernard J, Fauvel J, Massip P, Ruidavets JB, Perret B: Association of APOC3 polymorphisms with both dyslipidemia and lipoatrophy in HAART-receiving patients. AIDS Res Hum Retroviruses 2008, 24:169-71.

48. Lahiry P, Ban MR, Pollex RL, Feldman RD, Sawyez CG, Huff MW, Young TK, Bjerregaard P, Hegele RA: Common variants APOC3, APOA5, APOE and PON1 are associated with variation in plasma lipoprotein traits in Greenlanders. Int I Circumpolar Health 2007, 66:390-400.

49. Parzianello L, Oliveira G, Coelho JC: Apolipoprotein CIII polymorphism and triglyceride levels of a Japanese population living in Southern Brazil. Braz J Med Biol Res 2008, 41:462-7.

50. Kawakami A, Osaka M, Tani M, Azuma H, Sacks FM, Shimokado K, Yoshida M: Apolipoprotein CIII links hyperlipidemia with vascular endothelial cell dysfunction. Circulation 2008, 118:731-42.

51. Ruiz JR, Labayen I, Ortega FB, Moreno LA, González-Lamuño D, Martí A, Nova E, Fuentes MG, Redondo-Figuero C, Martínez JA, Sjöström M, Castillo MJ, AVENA Study Group: Birth weight and blood lipid levels in Spanish adolescents: influence of selected APOE, APOC3 and PPARgamma2 gene polymorphisms. The AVENA Study. BMC Med Genet 2008, 9:98.

52. Yiyang $L$, Ruixing $Y$, Meng $L$, Kela $L$, Xingjiang $L$, Lin Z, Wanying $L$, Shangling P, Dezhai $Y$, Weixiong L: Apolipoprotein C-III gene polymorphism and several environmental factors with serum lipid levels in the Guangxi Hei Yi Zhuang and Han populations. J Investig Med 2010, 58:777-85.

53. Tsai MY, Ordovas JM: APOC3 mutation, serum triglyceride concentrations, and coronary heart disease. Clin Chem 2009, 55:1274-6.

54. Zhang Q, Liu Y, Liu BW, Fan P, Cavanna J, Galton DJ: Common genetic variants of lipoprotein lipase and apolipoproteins Al-CIII that relate to coronary artery disease: a study in Chinese and European subjects. $\mathrm{Mol}$ Genet Metab 1998, 64:177-83.

55. Russo GT, Meigs JB, Cupples LA, Demissie S, Otvos JD, Wilson PW, Lahoz C, Cucinotta D, Couture P, Mallory T, Schaefer EJ, Ordovas JM: Association of the Sst-I polymorphism at the APOC3 gene locus with variations in lipid levels, lipoprotein subclass profiles and coronary heart disease risk: the Framingham offspring study. Atherosclerosis 2001, 158:173-81.

56. Olivieri O, Stranieri C, Bassi A, Zaia B, Girelli D, Pizzolo F, Trabetti E, Cheng S, Grow MA, Pignatti PF, Corrocher R: ApoC-III gene polymorphisms and risk of coronary artery disease. J Lipid Res 2002, 43:1450-7.

57. Baroni MG, Berni A, Romeo S, Arca M, Tesorio T, Sorropago G, Di Mario U, Galton DJ: Genetic study of common variants at the Apo E, Apo Al, Apo CIII, Apo B, lipoprotein lipase (LPL) and hepatic lipase (LIPC) genes and coronary artery disease (CAD): variation in LIPC gene associates with clinical outcomes in patients with established CAD. BMC Med Genet 2003, $4: 8$

58. Chhabra S, Narang R, Lakshmy R, Vasisht S, Agarwal DP, Srivastava LM, Manchanda SC, Das N: Apolipoprotein C3 Sstl polymorphism in the risk assessment of CAD. Mol Cell Biochem 2004, 259:59-66.

59. Payseur BA, Clark AG, Hixson J, Boerwinkle E, Sing CF: Contrasting multisite genotypic distributions among discordant quantitative phenotypes: the APOA1/C3/A4/A5 gene cluster and cardiovascular disease risk factors. Genet Epidemiol 2006, 30:508-18

60. Muendlein A, Saely CH, Marte T, Schmid F, Koch L, Rein P, Langer $P$, Aczel $S$, Drexel H: Synergistic effects of the apolipoprotein E epsilon3/ epsilon2/epsilon4, the cholesteryl ester transfer protein TaqIB, and the apolipoprotein C3 $-482 \mathrm{C}>\mathrm{T}$ polymorphisms on their association with coronary artery disease. Atherosclerosis 2008, 199:179-86.

61. Ruiz-Narváez EA, Sacks FM, Campos H: Abdominal obesity and hyperglycemia mask the effect of a common APOC3 haplotype on the risk of myocardial infarction. Am J Clin Nutr 2008, 87:1932-8.

62. Shanker J, Perumal G, Rao VS, Khadrinarasimhiah NB, John S, Hebbagodi S, Mukherjee M, Kakkar W: Genetic studies on the APOA1-C3-A5 gene cluster in Asian Indians with premature coronary artery disease. Lipids Health Dis 2008, 7:33.

63. Ruixing Y, Yuming C, Shangling P, Fengping $H$, Tangwei L, Dezhai $Y$, Jinzhen W, Limei $Y$, Weixiong $L$, Rongshan $L$, Jiandong $H$ : Effects of demographic, dietary and other lifestyle factors on the prevalence of hyperlipidemia in Guangxi Hei Yi Zhuang and Han populations. Eur J Cardiovasc Prev Rehabil 2006, 13:977-84.

64. Ruixing $Y$, Limei $Y$, Yuming $C$, Dezhai $Y$, Weixiong L, Muyan L, Fengping $H$, Jinzhen W, Guangqing $Y$, Zhenbiao N: Prevalence, awareness, treatment, control and risk factors of hypertension in the Guangxi Hei Yi Zhuang and Han populations. Hypertens Res 2006, 29:423-32.

65. De Oliveira E, Silva ER, Foster D, McGee Harper M, Seidman CE, Smith JD, Breslow JL, Brinton EA: Alcohol consumption raises HDL cholesterol levels by increasing the transport rate of apolipoproteins A-I and A-II. Circulation 2000, 102:2347-52.

66. Agarwal DP: Cardioprotective effects of light-moderate consumption of alcohol: a review of putative mechanisms. Alcohol Alcohol 2002, 37:409-15.

67. Rimm EB, Williams P, Fosher K, Criqui M, Stampfer MJ: Moderate alcohol intake and lower coronary heart disease: meta-analysis of effects on lipids and haemostatic factors. BMJ 1999, 319:1523-8.

68. Savolainen MJ, Kesaniemi YA: Effects of alcohol lipoproteins in relation to coronary heart disease. Curr Opin Lipidol 1995, 6:243-50.

69. Ko YL, Ko YS, Wu SM, Teng MS, Chen FR, Hsu TS, Chiang CW, Lee YS: Interaction between obesity and genetic polymorphisms in the apolipoprotein CIII gene and lipoprotein lipase gene on the risk of hypertriglyceridemia in Chinese. Hum Genet 1997, 100:327-33.

70. Bai H, Saku K, Liu R, Imamura M, Arakawa K: Association between coronary heart disease and the apolipoprotein A-I/C-III/A-IV complex in a Japanese population. Hum Genet 1995, 95:102-4.

71. Marcil M, Boucher B, Gagné E, Davignon J, Hayden M, Genest J Jr: Lack of association of the apolipoprotein A-I-C-III-A-IV gene Xmnl and Sstl polymorphisms and of the lipoprotein lipase gene mutations in familial combined hyperlipoproteinemia in French Canadian subjects. J Lipid Res 1996, 37:309-19.

72. Kee F, Amouyel P, Fumeron F, Arveiler D, Cambou JP, Evans A, Cambien F, Fruchart JC, Ducimetière $P$, Dallongeville J: Lack of association between genetic variations of apo A-I-C-III-A-IV gene cluster and myocardial infarction in a sample of European male: ECTIM study. Atherosclerosis 1999, 145:187-95.

73. Thu NN, Mai TT, Ohmori R, Kuroki M, Chuyen NV, Hung NT, Kawakami M, Kondo K: Plasma triglyceride and $\mathrm{HDL}$-cholesterol concentrations in Vietnamese girls are affected by lipoprotein lipase, but not apolipoprotein CIII polymorphism. J Nutr 2006, 136:1488-92.

74. Ruidavets $\mathrm{J} B$, Ducimetière $P$, Arveiler $D$, Amouyel $P$, Bingham $A$, Wagner $A$, Cottel D, Perret B, Ferrières J: Types of alcoholic beverages and blood lipids in a French population. J Epidemiol Community Health 2002, 56:24-8.

75. Choudhury SR, Ueshima H, Kita Y, Kobayashi KM, Okayama A, Yamakawa M, Hirao Y, Ishikawa M, Miyoshi Y: Alcohol intake and serum lipids in a Japanese population. Int J Epidemiol 1994, 23:940-7.

doi:10.1186/1476-511X-9-86

Cite this article as: Ruixing et al:: Interactions of the apolipoprotein C-III

$3238 \mathrm{C}>\mathrm{G}$ polymorphism and alcohol consumption on serum

triglyceride levels. Lipids in Health and Disease 2010 9:86. 